Original Research Article

\title{
Finger-tip injuries: a study on functional outcomes of various methods of treatment
}

\author{
Hitesh Singhal*, Nirottam Singh, Aviral Gupta, D. S. Meena
}

Department of Orthopedics, SMS Medical College, Jaipur, Rajasthan, India

Received: 14 March 2020

Revised: 13 April 2020

Accepted: 21 April 2020

\author{
*Correspondence: \\ Dr. Hitesh Singhal, \\ E-mail: hiteshsinghal35@gmail.com
}

Copyright: $\odot$ the author(s), publisher and licensee Medip Academy. This is an open-access article distributed under the terms of the Creative Commons Attribution Non-Commercial License, which permits unrestricted non-commercial use, distribution, and reproduction in any medium, provided the original work is properly cited.

\begin{abstract}
Background: Fingertip injuries are the most common injuries of the hand. Although maintenance of length, preservation of the nail, and appearance are important, the primary goal of treatment is a painless fingertip with durable and sensate skin. Restoration of original form or reconstruction of the most comfortable and functional compromise is the substance of challenge assured by the surgeon who manages the injured fingertip.

Methods: This descriptive study was done to evaluate the outcomes of various management (conservative, primary closure, SSG and various flaps) of fingertip injuries of 180 patients from December 2014 to 2016.

Results: Out of 180 patients, 30 dropped out, $76 \%$ were males and $24 \%$ were females. $68 \%$ were children and labor class. Index finger was involved in 55\% cases. $42 \%$ injuries were due to machine injuries and door entrapment. Conservative and cross finger flap has better outcomes.

Conclusions: This is a preliminary report of 150 cases of the fingertip injuries with the problem of tissue loss. Most patients were injured while working. Majority of trauma was caused by various machines. Various methods had been chosen depends on type of injuries, age and occupation.
\end{abstract}

Keywords: Fingertip, Primary closure, Split skin graft, Cross finger flap

\section{INTRODUCTION}

Fingertip injuries are the most common injuries of the hand. It includes structures as skin, subcutaneous tissue and bone of fingertip, nail and nail bed. Although maintenance of length, preservation of the nail, and appearance are important, the primary goal of treatment is a painless fingertip with durable and sensate skin. ${ }^{1}$ The human hand may come in direct contact with numerous objects such as kutty machines, fast moving machines, knives, glasses, hammer blows, entrapment in door, pulleys, stone etc. These injuries may involve damage to fingertip in form of simple laceration without tissue loss to partial detachment, loss of tissue, nail and nail bed, loss of distal phalanx bone can occur in amputation or slicing injuries to the hand. Restoration of original form or reconstruction of the most comfortable and functional compromise is the substance of challenge assured by the surgeon who manages the injured fingertip. The human hand carried sensory and prehensile work so every effort should be made to restore it back to normal.

The proper method is selected for management of fingertip injuries with a view of type of injuries and method of treatment will be assessed.

Treatment goals in our study include pain relief, shortest time required for healing, good aesthetic appearance and short duration of functional impairment and supple joint. ${ }^{2}$ Our objective was to evaluate the functional outcomes of various methods of treatment. 


\section{METHODS}

A study was conducted in the hand surgery unit in Department of Orthopedics, S.M.S. Hospital, Jaipur on cases of hand injuries admitted in hospital with the problem of fingertip injuries having tissue loss.

It is descriptive study to evaluate the outcomes of various management (conservative, primary closure, SSG and various flaps) of fingertip injuries in 180 patients from December 2014 to 2016. All the data was analysed in microsoft excel. Following types of cases were selected: amputation of digit, loss of skin on dorsal surface with or without nail and nail bed injuries, loss of skin on volar aspect of digit with or without bony injuries. Crush injuries of finger where there was tissue loss in form of skin avulsion or and nail bed or bony loss. Partial or near total amputations.

Plan of reconstruction was made after proper examination of injury depending upon type of injuries, mechanism of injuries, age and occupation of patient, time since injured, facilities available in department and experience of surgeon who carried out these treatments. Depending upon type and mechanism of injuries and age and occupation, any of the following procedure was carried out primary closure, primary closure following minimal nibbling of bone, pulp reposition, conservative treatment, and plastic procedure - split skin grafting, cross finger flap, thenar flap, kutler flap, atasoy V-Y plasty, and remote flaps.

All the patients recorded were operated upon and followed by the same team of surgeons to ensure uniformity of treatment. As far as possible a clinical photograph was taken after completion of treatment.

All the cases were instructed to visit the orthopedic outdoor for dressing and further follow up. On first dressing condition of graft or flap, presence or absence of infection and collection with condition of adjacent skin noted. Subsequent dressing was done as and when indicated. Collection if present was removed. Stitch was removed at about $10^{\text {th }}$ day. Six weeks after proper healing of wound clinical photograph of hand was taken and final evaluation was done on appearance of finger tips (skin color- match/pigmented/depigmented), (pulp-rounded/ atrophied/flat), (nail-absent/deformed/normal), sensation, movements, condition of donor site and time required for healing and off days from work.

The final result was graded into excellent, good, fair or poor depending upon restoration of finger length, time taken for healing, hand movements, return of sensation, off days from work, and cosmetic appearance.

\section{RESULTS}

The most common age group in our study were people in $3^{\text {rd }}$ decade $(65.33 \%)$ and least were old age and majority were males (Table 1). Maximum number of injuries occurred in children (44\%), followed by labor (24.67\%), housewife $(11.33 \%)$ and least incidence in professional (Table 2). Maximum incidence of injuries occurred in index and middle fingers owing to long length and used commonly in pinch and power grasp. Most common cause of injury is machine injuries (30.67\%) followed by entrapment injuries (22\%), followed by kutty machine injuries $(17.33 \%)$. Majority of injuries were caused by sharp cut $(57.33 \%)$ i.e. mostly due to machine injuries. Majority of injury occur in right hand which is commonly dominant hand $(59.33 \%)$. Maximum method carried out were conservative procedures (44\%), followed by primary closure (32\%). Color match was maximum (all cases) in primary closure and conservative followed by $\mathrm{v}$ y flap and moberg flap. Hyperpigmentation was in almost all cases of CFF and SSG (Table 3). Pulp was round in all cases of plastic, conservative and primary closure. Pulp was flat in all cases of SSG procedures (Table 3).

Table 1: The demographic pattern of the patients.

\begin{tabular}{|lll|}
\hline Age group (in years) & Number & Percentage (\%) \\
\hline Upto 10 & 26 & 17.33 \\
\hline $\mathbf{1 1}$ to 20 & 29 & 19.33 \\
\hline $\mathbf{2 1}$ to 30 & 43 & 28.67 \\
\hline $\mathbf{3 1}$ to 40 & 25 & 16.67 \\
\hline $\mathbf{4 1}$ to 50 & 16 & 10.67 \\
\hline $\mathbf{5 1}$ to 60 & 9 & 6.00 \\
\hline$>$ 60 & 2 & 1.33 \\
\hline Total & 150 & 100.00 \\
\hline
\end{tabular}

Table 2: Occupational distribution.

\begin{tabular}{|lll|}
\hline Variables & Number & Percentage (\%) \\
\hline Child & 66 & 44.00 \\
\hline Farmer & 12 & 8.00 \\
\hline Housewife & 17 & 11.33 \\
\hline Labour & 37 & 24.67 \\
\hline Professional & 2 & 1.33 \\
\hline Pujaari & 1 & 0.67 \\
\hline Sedentary worker & 8 & 5.33 \\
\hline Shopkeeper & 2 & 1.33 \\
\hline Student & 2 & 1.33 \\
\hline Teacher & 1 & 0.67 \\
\hline Typewriter & 1 & 0.67 \\
\hline Ward boy & 1 & 0.67 \\
\hline Total & 150 & 100.00 \\
\hline
\end{tabular}

Table 4 shows that hyperesthesia (tenderness) was maximum in SSG (62.96\%), stiffness in CFF and thenar flap $10.38 \%$ and $50 \%$ respectively. Conservative and primary closure shows no hyperesthesia and stiffness (Table 4). Average healing days in primary closure were 17 days, conservative 28.64 days, CFF 37.69 days, SSG 25.89 days, thenar flap 41.83 days, V-Y flap 18 days (Table 5). 
Table 3: Association of operative procedure with condition of fingertip.

\begin{tabular}{|c|c|c|c|c|c|c|c|c|c|}
\hline \multirow{2}{*}{ Variables } & \multicolumn{3}{|c|}{ Condition of fingertip skin } & \multicolumn{3}{|l|}{ Pulp } & \multicolumn{3}{|l|}{ Nail } \\
\hline & $\begin{array}{l}\text { Color } \\
\text { match }\end{array}$ & $\begin{array}{l}\text { Hyper } \\
\text { pigment }\end{array}$ & Nil & Flat & Nil & Round & Absent & Deformed & Normal \\
\hline Composite graft & 2 & & & & & 2 & & & 2 \\
\hline Moberg flap & 3 & & & & & 3 & & & 3 \\
\hline Pulp reposition & 2 & & & & & 2 & & & 2 \\
\hline Conservative & 44 & & & & & 44 & & 3 & 41 \\
\hline Cross finger flap & 3 & 26 & & & & 29 & & 4 & 25 \\
\hline Thenar flap & 6 & & & & & 6 & & & 6 \\
\hline SSG and V-Y flap & 1 & & & & & 1 & & & 1 \\
\hline Abdominal flap & 1 & & & & & 1 & & & 1 \\
\hline SSG & & 1 & & 1 & & & & & 1 \\
\hline Primary closure & 31 & & 1 & & 1 & 31 & 9 & 8 & 15 \\
\hline SSG & 1 & 26 & & 25 & & 2 & & 1 & 26 \\
\hline $\begin{array}{l}\text { V-Y and cross } \\
\text { finger flap }\end{array}$ & 1 & & & & & 1 & & & 1 \\
\hline
\end{tabular}

Table 4: Association of operative procedure with sensation.

\begin{tabular}{|c|c|c|c|c|c|c|}
\hline \multirow{2}{*}{ Variables } & \multirow[b]{2}{*}{ Total } & \multirow{2}{*}{$\begin{array}{l}\text { Sensation pain } \\
\text { Hyperaes }\end{array}$} & \multicolumn{2}{|l|}{ Touch } & \multicolumn{2}{|c|}{ Finger movements } \\
\hline & & & Hyperaes & Normal & Stiffness & Supple \\
\hline Composite graft & 2 & 0 & 0 & 2 & 0 & 2 \\
\hline Moberg flap & 3 & 0 & 0 & 3 & 0 & 3 \\
\hline Pulp reposition & 2 & 0 & 0 & 2 & 0 & 2 \\
\hline Conservative & 44 & 0 & 0 & 44 & 0 & 44 \\
\hline Cross finger flap & 29 & 0 & 0 & 29 & 3 & 26 \\
\hline Thenar flap & 6 & 0 & 0 & 6 & 3 & 3 \\
\hline SSG and V-Y flap & 1 & 0 & 0 & 1 & 0 & 1 \\
\hline Abdominal flap & 1 & 0 & 0 & 1 & 1 & \\
\hline Primary closure & 32 & 0 & 0 & 32 & 1 & 31 \\
\hline SSG & 28 & 13 & 18 & 10 & 2 & 26 \\
\hline $\begin{array}{l}\text { V-Y and cross finger } \\
\text { flap }\end{array}$ & 1 & 0 & 0 & 1 & 0 & 1 \\
\hline V-Y flap & 1 & 0 & 0 & 1 & 0 & 1 \\
\hline Total & 150 & & 18 & 132 & 9 & 141 \\
\hline
\end{tabular}

Table 5: Association of operative procedure with healing time.

\begin{tabular}{|llllll|}
\hline Variables & N & Mean & SD & Minimum & Maximum \\
\hline Abdominal flap & 1 & 50.00 & & 50 & 50 \\
\hline Composite graft & 2 & 19.00 & 1.414 & 18 & 20 \\
\hline Conservative & 44 & 28.64 & 4.808 & 16 & 40 \\
\hline Cross finger flap & 29 & 37.69 & 8.957 & 14 & 50 \\
\hline Moberg flap & 3 & 20.33 & 0.577 & 20 & 21 \\
\hline Primary closure & 32 & 17.00 & 2.229 & 14 & 25 \\
\hline Pulp reposition & 2 & 17.00 & 4.243 & 14 & 20 \\
\hline SSG & 28 & 25.89 & 9.049 & 20 & 60 \\
\hline SSG and V-Y flap & 1 & 14.00 & - & 14 & 14 \\
\hline Thenar flap & 6 & 41.83 & 4.262 & 35 & 46 \\
\hline V-Y flap & 1 & 18.00 & - & 18 & 18 \\
\hline Total & 149 & 27.44 & 10.039 & 14 & 60 \\
\hline
\end{tabular}


Table 6: Association of operative procedure with off days from work.

\begin{tabular}{|llll|}
\hline Variables & N & Mean & SD \\
\hline Abdominal flap & 1 & 60.00 & - \\
\hline Composite graft & 2 & 19.00 & 1.414 \\
\hline Conservative & 44 & 28.43 & 4.939 \\
\hline Cross finger flap & 29 & 39.90 & 6.258 \\
\hline Moberg flap & 3 & 20.33 & .577 \\
\hline Primary closure & 32 & 17.00 & 2.229 \\
\hline Pulp reposition & 2 & 17.00 & 4.243 \\
\hline SSG & 27 & 25.67 & 9.140 \\
\hline SSG and V-Y flap & 1 & 15.00 & - \\
\hline Thenar flap & 6 & 42.67 & 2.944 \\
\hline V-Y flap & 1 & 18.00 & - \\
\hline V-Y and cross finger flap & 1 & 45.00 & - \\
\hline Total & 149 & 28.00 & 10.436 \\
\hline
\end{tabular}

Average period of off days was maximum in plastic procedures such as abdominal flap, cross finger flap, thenar flap. It took nearly double of other procedures. Primary closure took 17 days, conservative 28.43 days, SSG 25.67, CFF 39.90 days, V-Y plasty 18 days (Table 6).

\section{DISCUSSION}

In developing countries such as ours, the rapid growth of mechanized farming and relatively large number of populations of unskilled labor predispose them to trauma, resulting in increased incidence of hand injuries. ${ }^{3}$ There were a large number of patients in this study admitted with fingertip injuries. Majority of patients were from rural areas and were laborers. There was a large drop out in follow up (30 patients out of 180). This could be contributed to poor socio-economic status and distance, and patients who were satisfied merely by wound healing. Most of work was done in western countries and their data shows good follow up. This is attributed to literacy, educated paramedical staff. Most of people are insured so they lose little if they come for follow up. Our follow up is ranging from 2-18 months which is far data presented about. The reason is well understood. The maximum incidence of injuries occurs in the 10-30 years age group as this is the group which is involved in manual productivity. Our study shows that the most common age group was 21-30 years which falls in the manual production group. Children of $0-10$ years are also in nearly equal number, as these children are commonly injured while playing around with kutty mechanism and hand pump. Holm and Zachariae concluded that most patients were found in the manual production group (15-30) years. ${ }^{3}$

Observations shows that most victims are males. Holm and Zachariae, Tupper and Miller concluded similar findings. This could be attributed to firstly less mechanical work done by females and secondly, they stay home. The common cause of injuries were various machines followed by equipment used in farming. These are a common cause of rural trauma. Kutty machines can cause slicing or crushing injuries depending upon where the hand is entrapped. Brody and Horner concluded that machines were the main source of fingertip injuries. ${ }^{4}$ Holm and Zachariae concluded that increased number of injuries were due to mechanization and involvement of untrained personal with these machines and over work. ${ }^{3}$

The index and middle finger were involved more with significant trauma to the thumb also. These three digits are more vulnerable to trauma because they are the most used digits, the index and middle being largest is more exposed and therefore more vulnerable. Brody showed that the frequency of injuries is directly related to their length. Moynihan, Tupper and Miller also observed similar incidence. $^{5,6}$

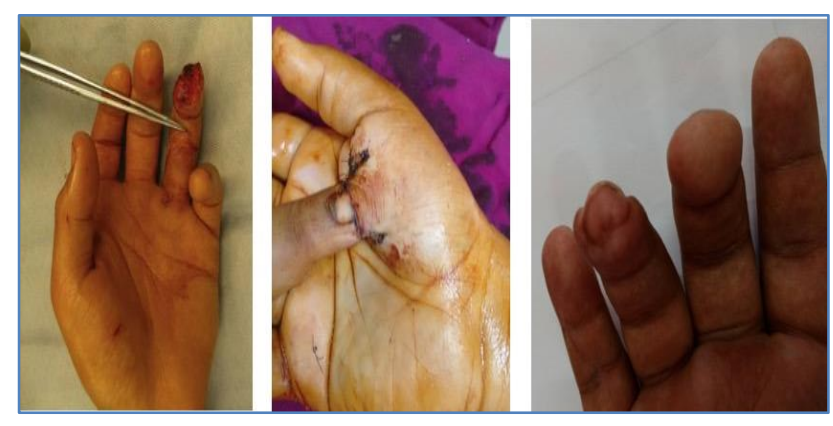

Figure 1: Thenar flap.

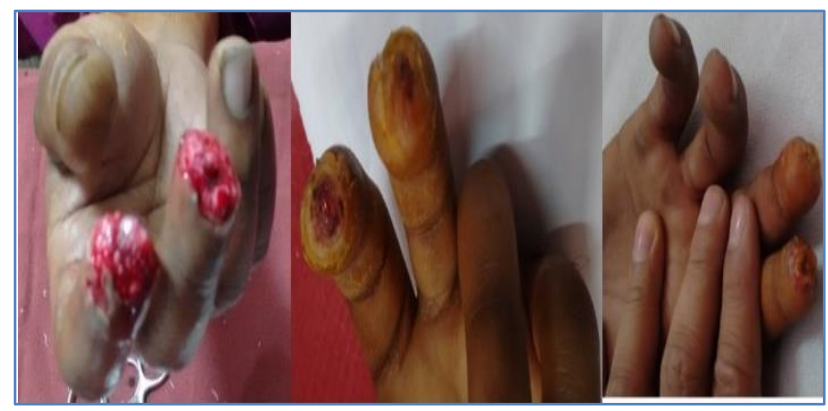

Figure 2: Conservative. 
Primary closure of the wounds of digits is the procedure of choice in patients having tissue loss, bone involvement or amputations. Our patients belonging to low socioeconomic group, mostly daily wagers who are in hurry to return to work as soon as possible. ${ }^{7}$ Good or excellent results were achieved in all patients treated by primary closure with well-padded and sensate skin. Conservative management (Figure 2) was done for the patient having severe crushing of the tip or patients reporting late but having adequate soft tissue for cover were treated conservatively. ${ }^{8}$ At the end of treatment, the finger tips were found to have a good sensitive pulp though frequently nails were deformed. Maximum length could be preserved by this method. SSG (Figure 3) was useful in patient having a skin and soft tissue loss but the bone is not exposed or minimally exposed and where early return to work was crucial. ${ }^{9,10}$ Most patients in our study were manual workers and they were primarily concerned with wound healing and it contributed to early return to work but there was hyperpigmentation of the grafted skin and deformation of nails also occurs. There is instability of grafts, when work was done against hard objects. CFF (Figure 4) was carried out when the raw area is situated on volar aspects of the fingertip. ${ }^{11-13}$ This procedure gives a good, padded, tough pulp with good contours. The flaps were always pigmented as they were taken from the dorsal aspect of the adjacent digits. There is slight disfigurement of the donor site with chances of entrapment of tendon if the flap raised is too deep. Thenar flap (Figure 1) can be used for covering the wound on the tip of finger, where loss of pulp is present and bone is exposed. ${ }^{14,15}$ It gives better results where minimum bone and nail is missing. This gives a tough, permanent and adequately padded cover. There is also a good color match as donor skin is taken from thenar eminence.
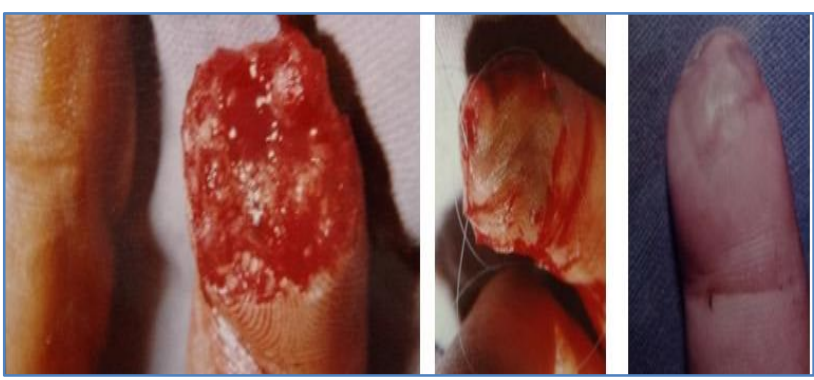

Figure 3: SSG.

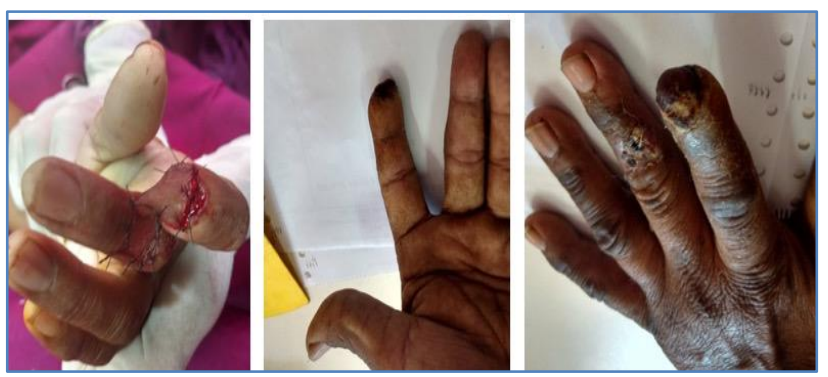

Figure 4: Cross finger flap.
Finger is to be immobilized in extreme flexion so stiffness of the finger is a common sequel. Kutler V-Y plasty and atasoy V-Y plasty: this operation is carried out in transverse amputation where restoration of length is important ${ }^{16}$ For this procedure to be carried out, some part of nail must remain. The result in our cases were excellent with good padded finger tips with preserved finger length but this is technically demanding.

\section{CONCLUSION}

The various methods of treatment under taken were in accordance with the need of patients. The primary closure is method of choice when good sensation, early healing is desired, but it fails to provide restoration of maximum possible finger length. Split skin grafting is method of choice when patients is manual worker and soft tissue cover is possible. This shows shrinkage with time and become less perceptible. This operation is simple and patients could return to work earliest. Conservative method is method of preference when patients reported late or had infection, bone should not be exposed. This procedure gives maximum possible finger length with no complication. The cross finger, thenar flap and V-Y plastics are done when there is demand of profession for sensation or restoration of length or cosmesis. These are technically demanding and patients take a long time for return to work. The fingertip injuries are surgical emergencies. They should be handled by experienced staff. In different attitude and callousness in treating these injuries will result in markedly scarred hand, stiff joints, raw area. The function of hand is far from satisfaction. Thus, it is felt that acutely injured fingertip requires a little attention and cases than usual, to achieve better. And this study will help in opting method of fingertip injury in accordance with age, occupation, type of injury and need of patient.

\section{Funding: No funding sources}

Conflict of interest: None declared

Ethical approval: The study was approved by the institutional ethics committee

\section{REFERENCES}

1. Fassler PR. Fingertip Injuries: Evaluation and Treatment. J Am Acad Orthop Surg. 1996;4:84-92.

2. Beasley RW. Reconstruction of amputated fingertips. Plast Reconstr Surg. 1969;44:349-52.

3. Holm A, Zacharice L. Fingertip lesions: an evaluation of conservative treatment versus free skin grafting. Acta ortho scand. 1974;45:382.

4. Brody GS. The finger - tip injury. An assessment of management. Plast Reconstruction Surg. 1960;26:80.

5. Moynihan FJ. Long term results of split skin grafting in fingertip injuries. Brit Med J. 1961;2:802.

6. Tupper J, Miller G. Sensitivity following volar V-Y plasty for fingertip amputations. J Hand Surg Br. 1985;10(2):183-4. 
7. Andrew J. Miller. Fingertip Amputation Treatment: A Survey Study. Am J Orthop; 2015: 331-9.

8. Allen MJ. Conservative treatment in fingertip injuries in adults. Hand. 1980;12:3.

9. Dupertuis SM. Evaluation of skin grafts for hand coverage. J Bone Joint Surg. 1952;34:811.

10. Zadik FR. Immediate skin grafting for traumatic amputation of finger tips. Lancet. 1943;1:335.

11. Sueur D, Radivojevic M. Cross fingertip: A new technique. J Hand Surg. 1985;10:425.

12. Kappel DA, Burech JG. The cross-finger flap; an established reconstructive procedure. Hand Clin. 1985;1:677-83.

13. Nishikawa H, Smith PJ. The recovery of sensation and function after cross finger flap for fingertip injury. J Hand Surg. 1992;17:102-7.

14. Gottlieb O, Mathiesen FR. Thenar flaps and cross finger flaps. Acta. Chir Scand. 1961;122:166.
15. Melone CP, Beasley RW, Carstens JH. The thenar flap; an analysis of its use in 150 cases. J Hand Surg (Am). 1982;7:291-7.

16. Furlow JR. V-Y Cup flap for volar oblique amputations of finger. J Hand Surg. 1984;9:253.

17. Sorock GS, Lombardi DA, Hauser RB, Eisen EA, Herrick RF, Mittleman MA. Acute traumatic occupational hand injuries: type, location, and severity. J Occup Environ Med. 2002;44(4):345-51.

18. Chao JD, Huang JM, Wiedrich TA. Local hand flaps. J Am Soe Surg Hand. 2001;1(1):25-44.

19. Saraf S. Fingertip injuries. Indian J Orthop. 2007;41:163-8.

Cite this article as: Singhal H, Singh N, Gupta A, Meena DS. Finger-tip injuries: a study on functional outcomes of various methods of treatment. Int J Res Orthop 2020;6:767-72. 